\title{
集束プロトンビーム描画による微細加工と応用
}

\author{
正 員 西川 宏之*
}

\section{Challenges in the Micromachining by Proton Beam Writing and its Applications \\ Hiroyuki Nishikawa*, Member}

\begin{abstract}
Proton beam writing (PBW) is a direct writing technique for the fabrication of micro- and submicron-scale structures with high-aspect ratio. The straight trajectory of $\mathrm{MeV}$ protons incident to target materials allows high-aspect-ratio micromachining with high throughput, when compared with a conventional direct writing process using low-energy electron beam. The principles and superior features of the PBW technique are illustrated by demonstrating the micromachining by PBW on various resists. Application of the high-aspect-pillar structures by PBW is also demonstrated for electro-micro filters using dielectrophoresis.
\end{abstract}

キーワード：直接描画，プロトン，微細加工，レジスト，誘電泳動

Keywords : direct write, proton, micromachining, resist, dielectrophoresis

\section{1. はじめに}

近年，半導体集積回路をスケーリング則にしたがって一 層の微細化することにより，機能の高度化と低コスト化を 追求する“More Moore”という従来からの視点に加えて, 新 たに“More than Moore”(1) という視点から, MEMS（微小電子 機械システム) ${ }^{(2)}$ や微小流体流路 ${ }^{(3)}$ など多様な機能要素の複 合化による新規デバイスの創成を支援する新しい微細加工 技術への注目が集まっている。

本稿にて解説するイオンビームを利用した微細な表面改 質, 加工技術, 特にプロトンを利用した技術は, “Proton Beam Writing”（プロトンビーム描画）と呼ばれ，PBW と略され $る^{(4)}$ 。

この $\mathrm{PBW}$ 技術の開発により, 電子ビーム $(\mathrm{EB})$ 描画 ${ }^{(5)}$ や光リソグラフィ技術 ${ }^{(6)}$ では実現不可能な高アスペクト比 の形成を実現することで，上記に記したようなデバイス機 能の多様化の観点から三次元微細加工の新たな可能性を拓 くことが出来ると我々は考えている。

本稿では，まず PBW の基盤となるビーム発生・制御から 材料・プロセス, デバイス応用, 小型装置開発に至るまで の包括的取り組みについて解説する。

2. PBW とは

〈2·1〉 PBW による微細加エプロセス PBW とは， ミクロンからサブミクロンサイズに集束した $\mathrm{MeV}$ （百万電

\footnotetext{
芝浦工業大学 工学部 電気工学科

T135-8548 東京都江東区豊洲 3-7-5

Department of Electrical Engineering, Shibaura Institute of Technology

3-7-5, Toyosu, Koto-ku, Tokyo 135-8548
}

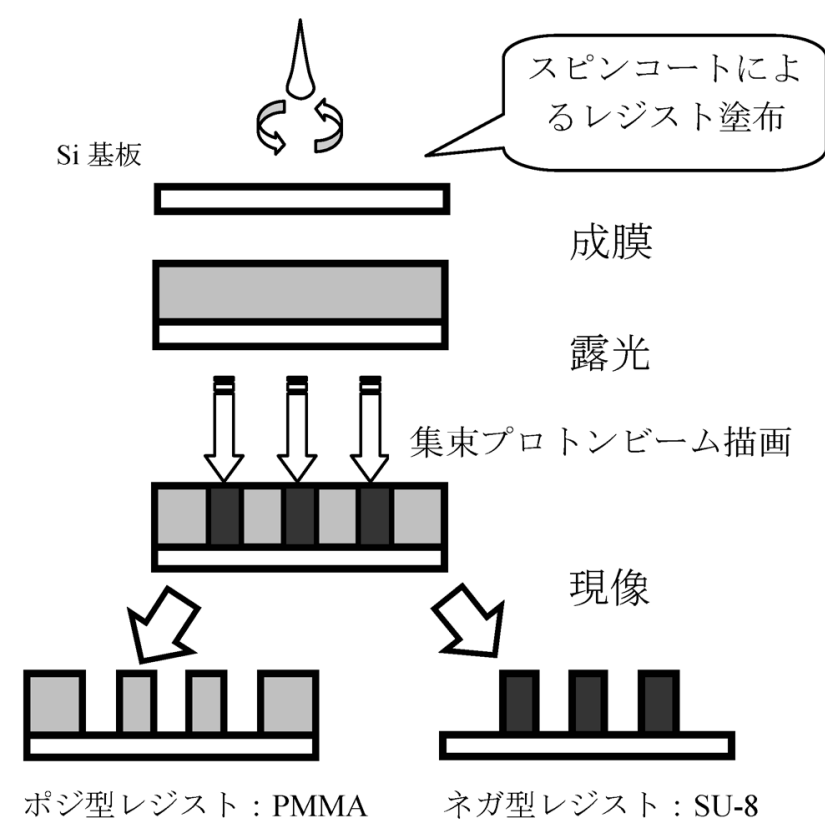

Fig. 1. Typical micromachining processes of exposure by PBW and development for positive-type PMMA and negative-type SU-8.

子ボルト）オーダーのエネルギーを持つプロトン（ $\mathrm{H}^{+}$, 陽 子）ビームを走査しながら描画する技術である。典型的な PBW の露光プロセスを Fig.1 に示す。PBW の加工対象は一 般にレジストと呼ばれる感光性の有機物である。

PBW 技術は 1997 年頃より国立シンガポール大学 (National University of Singapore, NUS) イオンビーム応用セ ンターの Watt 教授らにより開発が進められてきた ${ }^{(4)}$ 。NUS では, ビーム集束・描画システム, 露光および前後プロセ 


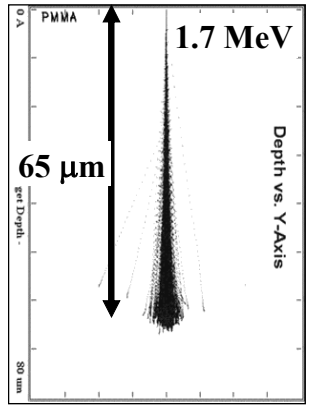

(a) $1.7 \mathrm{MeV}$ プロトン

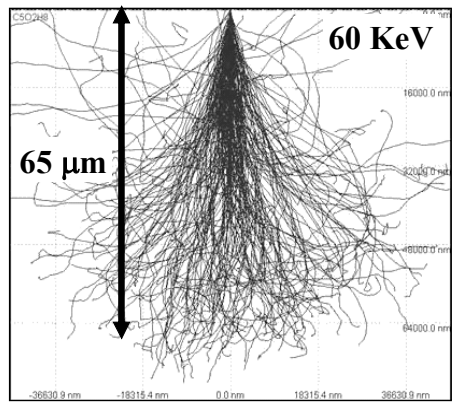

(b) $60 \mathrm{KeV}$ 電子
Fig. 2. Trajectories of $1.7-\mathrm{MeV}$ proton and $60-\mathrm{keV}$ electrons incident into PMMA obtained by SRIM and CASINO simulations.

スの研究開発が進められ, 現在 $20 \mathrm{~nm}$ に近いビーム集束が実 現されている(7)。2002 年以降, 隔年で PBW に関するワーク ショップが開催され, 日米欧の高エネルギーイオン加速器 を有する研究機関において推進されている。PBW 技術は, 後述のように既存のリソグラフィ手法に比べて原理的に優 れた点も多いが，同時に実用化に向けての課題もある。

PBW の優れた特徵は, $\mathrm{MeV}$ オーダーのエネルギーを有す るプロトンの物質中での直進性, およびその侵入深さの制 御性にあり，ともに加工の微細度と深さに関係する。PMMA に $1.7 \mathrm{MeV}$ のプロトンビームを照射した際のプロトンの飛

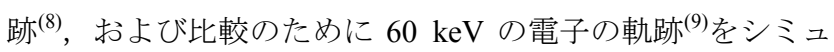
レーションした結果を Fig.2 (a) および (b) に示す。電子が 物質の表面近傍で強く散乱されるのに対し, プロトンは停 止する深さ (飛程) の直前に至るまで直進性を保っている。 これは, 電子に対してプロトンは約 1800 倍もの質量を有す るため, 物質中の電子と弾性衝突しても, ほとんど進行方 向を変えないことによる。この直進性を活かした高アスペ クト比加工が PBW の強みの一つである。

Fig.3 に PMMA 中でのプロトンのエネルギー損失の深さ 方向分のシミュレーション結果 ${ }^{(8)}$ を示す。これは, $1.7 \mathrm{MeV}$ あるいは $3.0 \mathrm{MeV}$ のエネルギーまで加速されたイオンが, 照 射対象の物質中での電子励起により非弾性的にエネルギー を失いながら停止する様子を示している。ここで注目す心゙ きは, 表面からイオンの停止する直前の深さまでエネルギ 一損失ほぼ一定の領域が存在することである。この領域で は, 非弾性的なエネルギー損失が支配的であり, 弾き出し に寄与する核衝突によるエネルギー損失は 3〜4 桁小さい。 このような高速イオン特有の, 他の放射線に比べて高い線 エネルギー付与（単位長さあたりのエネルギー損失, Linear Energy Transfer: LET）により，レジストを構成する分子鎖の 切断や架橋といった放射線化学反応が高密度に誘起され， 数 $10 \mu \mathrm{m}$ 程度の厚みをもつ高分子レジスト膜の露光が可能 となる。

その後イオンは Fig.3に示すようにその飛程の終端でエネ ルギー損失が極大值（ブラッグピーク）を示して停止する が，イオンの飛程はエネルギーを高くするほど大きくなる

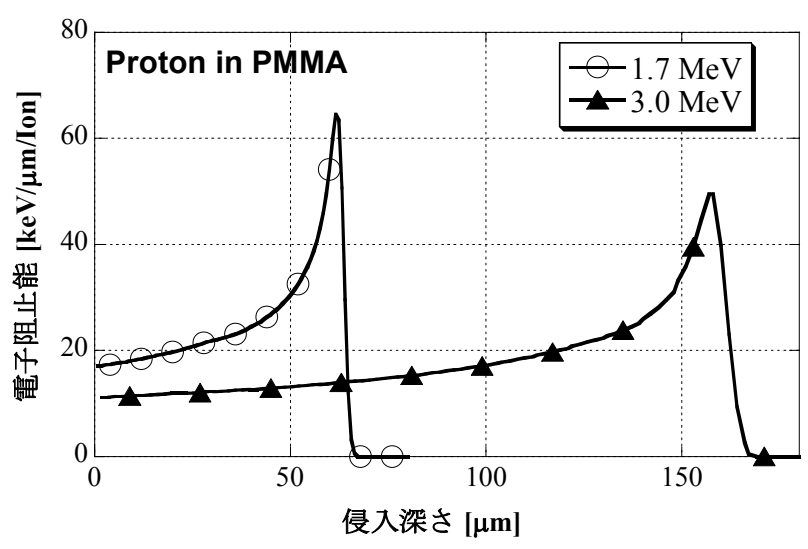

Fig. 3. Depth profiles of the electronic stopping powers for 1.7 $\mathrm{MeV}$ and $3.0 \mathrm{MeV}$ protons incident to PMMA obtained by SRIM simulations.

ので, 反応の深さ, 寸なわち加工深さをビームエネルギー により制御できる。UVやX 線による露光では, 物質中でエ ネルギー強度が指数関数的に減衰するが, イオンを用いた 加工では減衰しないため大きな特徵を生み出す。また, 装 置によりビーム強度は異なるために単純比較は出来ない が, $\mathrm{MeV}$ オーダーのイオンは数十 $\mathrm{keV}$ オーダーの電子に比 べて上述の LET が大きいため, 単位時間あたりの荷電粒子 の数が同じであれば，露光のスループットが高い。また， $\mathrm{MeV}$ オーダーのプロトンを用いる PBW においては, UV 光 によるリソグラフィ等で問題となる回折限界も十分小さ く, 100nm 級のビーム集束が実現されている ${ }^{(10)}$ 。

以上より, 既存の露光技術に対して, マスクレス描画に よる高い加工自由度, 露光の高速性, $100 \mathrm{~nm}$ 級の微細度と $100 \mu \mathrm{m}$ 級の加工深さを兼ね備える, という優れた特徵から PBW は自由度の高い微細加工を可能にする。

例えば, EB 描画技術と同様に, PBW では電界によりプロ トンビームをスキャンすることにより，Fig.4 (a)に示すよう な任意の文字描画を行うことが可能である。また，ドット 状の照射を行うことで Fig.4 (b)に示すような, 高アスペクト 比ピラー構造が形成される。さらに光の回折限界を超える 高い集束性能により, Fig.4 (c)のような $100 \mathrm{~nm}$ レベルのプ ロトンビームによる微細孔の形成も可能である。

〈2·2〉実験装置集束プロトンビームは, 日本原子 力研究開発機構 (JAEA) 高崎量子応用研究所放射線高度利 用施設 TIARA の $3 \mathrm{MV}$ シングルエンド型静電加速器と高エ ネルギーイオンマイクロ・ナノビーム形成装置（以下，形 成装置) により形成される ${ }^{(10)}$ 。数 $\mathrm{MeV}$ オーダーの軽イオン （水素及びヘリウム）により $250 \mathrm{~nm}$ のビーム径を達成し, 高 分解能イオンビーム分析 (PIXE 分析, RBS 分析等) に応用 している。その成果をさらに PBW に展開し ${ }^{(10)}$, 加工の微細 化 ・高精度化とともに加工面積の広範囲化に必要な技術開 発を行っている。

筆者らの研究グループは 2006 年度文部科学省私立大学学 術研究高度化推進事業（学術フロンティア）の採択を受け, 




(a)

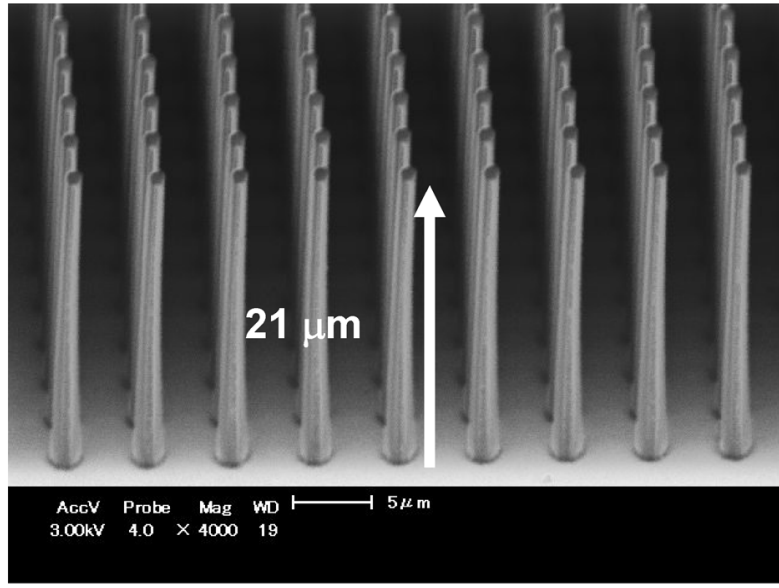

(b)

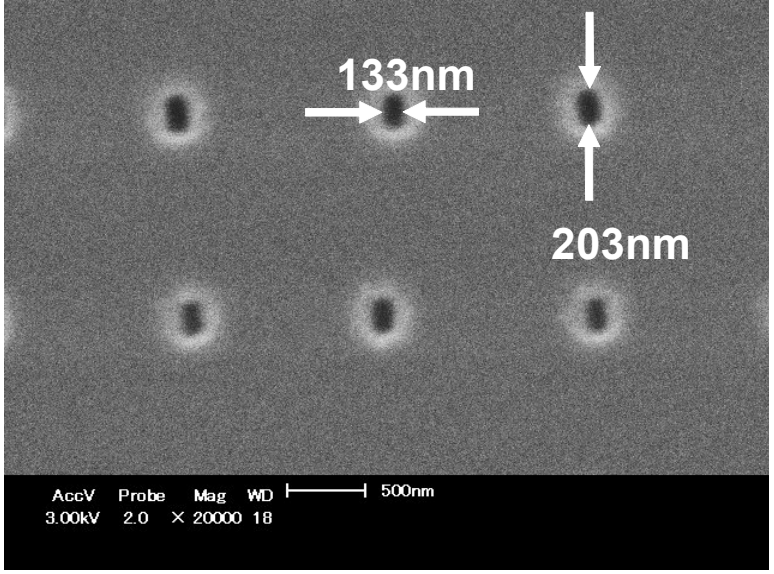

(c)

Fig. 4. (a) Characters drawn on 30-nm thick PMMA, (b) high aspect pillar arrays of $21-\mu \mathrm{m}$ thick SU-8, and (c) $100-\mathrm{nm}$ scale holes on PMMA.

芝浦工業大学先端工学研究機構内にフレキシブル微細加工 研究センター（Center for Flexible Micromachining, 以下 CFM）を設置した ${ }^{(12)}$ 。本研究は, 学内外から, 物理, 化学, 電子，通信，バイオ分野の研究者の力を結集し，PBWを基 軸とするものづくりの場を提供することを目的としてい る。

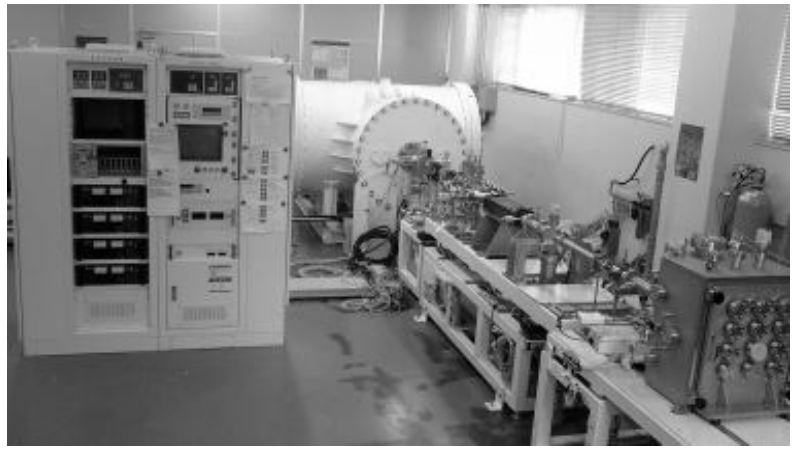

Fig. 5. Photograph of a compact PB writer installed at the center for flexible micromachining, Shibaura Institute of Technology. (A control panel on the left, a $1.0-\mathrm{MeV}$ single-ended accelerator at the center, a beamline and a sample chamber on the right).

$\mathrm{CFM}$ では 2006 年度に水素イオンビーム照射装置を設置 した。さらに 2007 年度のビーム集束系の付加により小型 PBW 装置として微細加工への利用を開始した。本装置はビ ームラインも含め $6 \times 7 \mathrm{~m}$ 程度のスペースに収まり，これま で普及の障害となっていた設置スペースの改善が図られて いる。CFM では本装置を PBW 技術普及のためのプラット フォームと位置づけ，一層の性能向上と $\mathrm{PBW}$ 装置の公開を 進めてゆく。

$\mathrm{CFM}$ のミッションは, その研究成果を公開し, PBWの普 及に努め，ものづくりの場を提供することである。現在， PBW によるものづくりの場を醸成するべく, 展示会等への 出展, シンポジウムの開催, ウェブサイトによる情報公開 ${ }^{(12)}$ を通じ，ポテンシャルユーザの開拓に取り組んでいる。

\section{PBW による微細加工例と応用}

〈3.1〉 三次元構造体の形成 PBW はプロトンビーム のエネルギーを変えることによって加工深さを制御できる という特徴を持つ。そこで厚膜ネガ型レジストである SU-8 (化薬マイクロケム社製) に対しビームエネルギーによって プロトンの飛程（加工深さ）を制御し, 三次元構造体の作 製を行った。Si 基板上に SU-8 を膜厚 $50 \mu \mathrm{m}$ で塗布した試料 に対し，ビームエネルギーの異なる 2 段階のプロトンビー ム描画を行った。これにより，レジストへの侵入深さ（飛 程）を変化させ, その後現像によりプロトンの達しない未 露光領域を除去することで三次元微細加工を行った。

Fig.6 に本手法で作製した中空構造を有する凱旋門型（芝 浦工業大学の豊洲キャンパス校舎をモデルとした）の三次 元構造体を示す。 $1.2 \mathrm{MeV}$ での照射（飛程 : $28 \mu \mathrm{m}$ ) により, 表面から深さ $28 \mu \mathrm{m}$ の構造が形成され, $3.0 \mathrm{MeV}$ での照射 （飛程：50 $\mu \mathrm{m}$ 以上）により高さ $50 \mu \mathrm{m}$ の支柱部分が形成さ れた。構造側面においては, 高エネルギープロトンの高い 直進性による垂直性の良好な構造が観測される ${ }^{(13)}$ 。

以上のように, PBW による微細加工ではビームエネルギ 一による飛程の違いを利用し厚膜レジスト中の三次元構造 


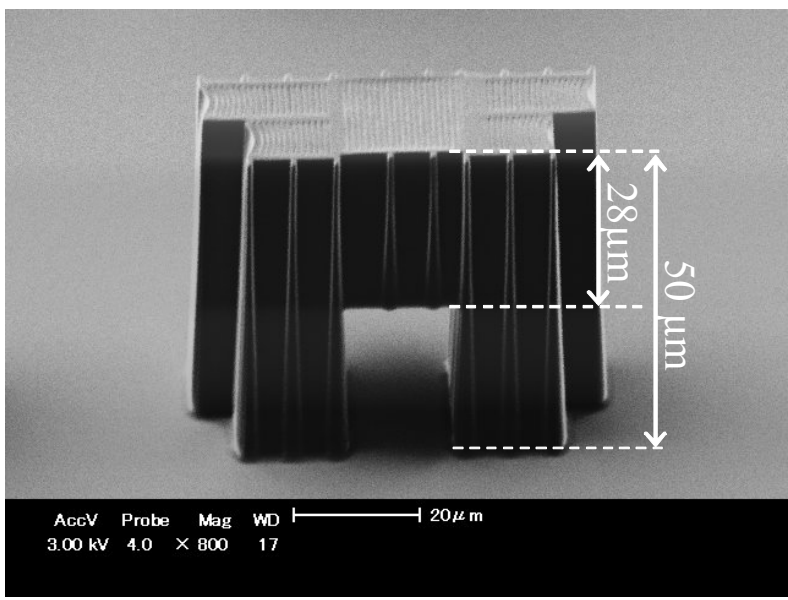

Fig. 6. A three dimensional Arc de Triomphe-like microstructure using PBW at multiple energies of 3.0 and 1.2 $\mathrm{MeV}$ exposure.

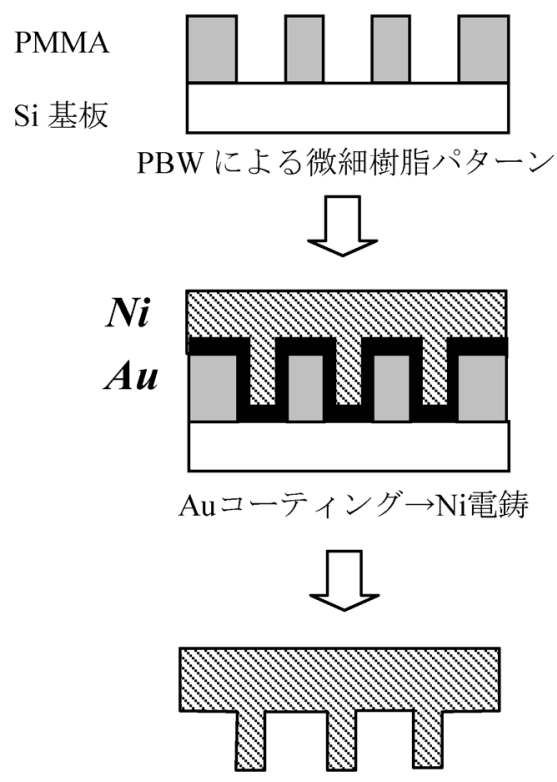

$\mathrm{Ni}$ 金型

Fig. 7. Electroplating of a microstructured Ni stamp using a micro-machined PMMA by PBW as a template.

体の形成が可能であることが示された。他に PBW による直 接描画により，高アスペクト比を有するライン\&スペース， ピラーなど種々の構造が形成されている ${ }^{(10)}$ 。

〈3·2〉 $\quad \mathrm{Ni}$ 電鋳による金型作製 $\quad \mathrm{PBW}$ の特徵を活かし た高アスペクト比を有する電鋳金型の作製例を紹介する (14)。Fig.7 に示す流れにより，基板上に PBW により形成し た微細パターンは，電鋳のための型として利用することで, 金型を形成することが出来る。Fig.8 (a)に示すように, PBW により作製した $5 \mu \mathrm{m}$ 厚の PMMA の微細パターンを母型と して, その後 Fig. 8 (b)に示すように Ni 電鋳により逆のパタ ーンが転写された。PBW の特徵である垂直かつ平滑な側面 を有する $\mathrm{Ni}$ 金型の形成が確認できた。これらの金型を用い

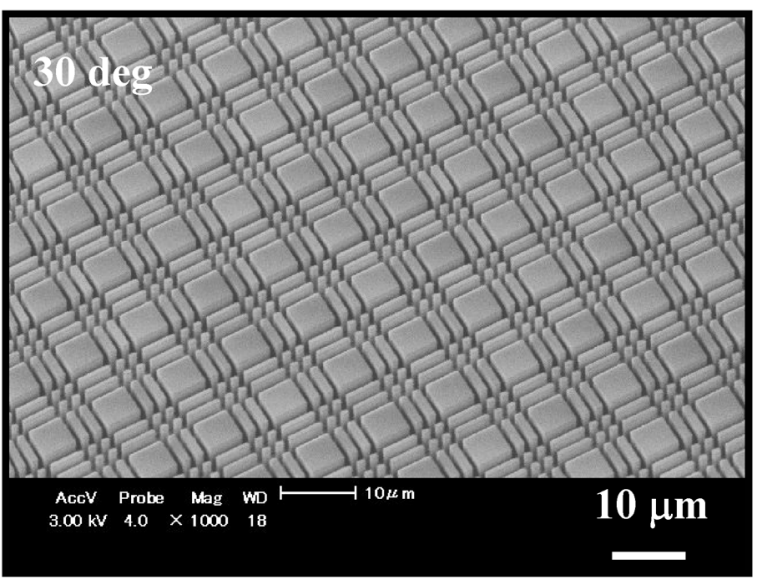

(a) 母型 PMMA における微細パターン

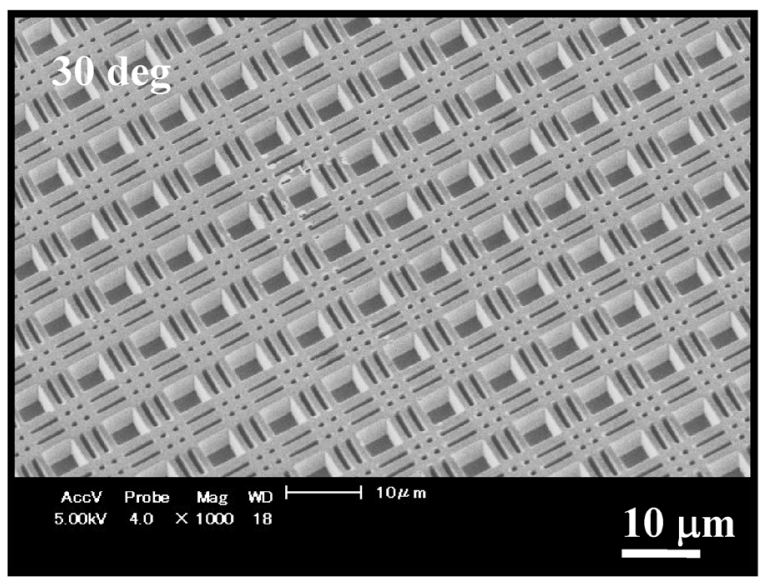

(b) 電鋳による Ni 転写パターン

Fig. 8. A micro-structured Ni stamp for imprint lithography using a micro-machined PMMA by PBW as a template.

た PMMA 等のインプリント実験を実施しているが，必ずし も容易ではない。特に高アスペクト比構造部分の形成には 離型性の向上が求められ，金型への表面処理が必要となる。

PBW により微細加工したパターンの PMMA を母型とし て，キャスティングにより，バイオチップの基幹材料とし てマイクロ流路の形成に用いられるポリジメチルシロキサ ン (Polydimethylsiloxane: PDMS) への転写を試みた ${ }^{(15)}$ 。同材 料は柔軟性があるため, キャスティング後, 離型が容易で あった。そのため Fig.9 (a)に示す PMMA のライン\&スペー スパターンが, Fig.9 (b)に示すように PDMS への良好なパタ ーン転写の結果が得られた。電鋳を介さずにレジストパタ ーンから直接転写可能な本プロセスは, PBW の高速な直接 描画性能高速を活かしたプロトタイピングに有用であると 考えられる。

〈3·3〉高アスペクト比構造の応用例ＰBWによる高 アスペクト比ピラー構造を利用した誘電泳動デバイス作製 の例 ${ }^{(16)}$ を紹介する。これは高アスペクト比を有するサブミ クロン三次元微細構造を形成し，これにより微生物捕集機 能と診断能力を有する新規な高機能, 高効率な誘電泳動 (dielectrophoresis: DEP) デバイスの創成を目指すものであ る。 


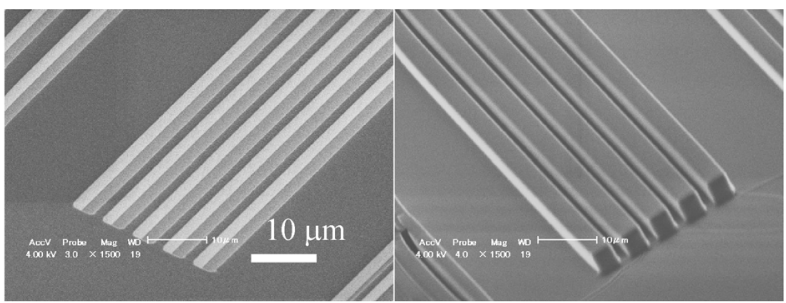

(a) 母型 (PMMA)

(b) 転写先 (PDMS)

Fig. 9. Replication of micro-machined PMMA by PBW into PDMS by a casting method.

誘電泳動とは，不均一電界中に置かれた誘電体微粒子に おいて，粒子左右に形成される電界強度の差に応じて，誘 起双極子が及ぼす力の差が発生し，微粒子に力が作用する 動電現象である。近年, 病原菌による集団食中毒などが社 会問題となる中, 食の安全・安心を守るための食品衛生管 理に関わる有力なデバイスである。電気的に誘電体とみな せる微生物の選択的濃縮・検出機能により培養プロセスを 介さず高速検出が可能となる ${ }^{(17)}$ 。

Fig.10 (a)に DEP デバイスの評価系を示す。Fig.10 (b)およ び (c) に示すような間隔の異なる誘電体ピラー $(12 \mu \mathrm{m}$ およ

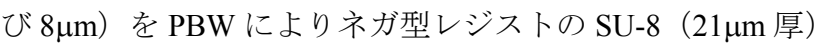
を用いて電極間（ギャップ距離 $200 \mu \mathrm{m}$ あるいは $400 \mu \mathrm{m}$ ）に 形成した。高密度な誘電体ピラーの存在下で電界が空間的 に変調され，ピラー近傍にて生じる不均一電界により誘電 泳動力の働く場の増加，ひいては誘電体微粒子を捕集する 場の密度の増大を狙いとしている。交流の電圧印加（振幅 $<100 \mathrm{~V}$ ，周波数 $<50 \mathrm{kHz})$ の下でサイズが $2 \mu \mathrm{m}$ 程度の大腸菌 の捕集効果を評価した。その結果，ピラー間隔が狭いほど 微生物捕集効果の向上が認められた ${ }^{(18)(19)}$ 。高密度に存在す る誘電体ピラーの存在による大腸菌の捕集サイトが増加し たと考えられる。また，ピラー高さが高いほど捕集効率が 高まることが確認され, 二次元方向の高密度化だけでなく, 三次元化がより効果的であることを示唆している。このこ とは高アスペクト比構造加工を得意とする PBW が DEP デ バイスの作製に有用であることを示している。

〈3.4〉レジスト材料の課題微細加工の対象とし て, MEMS 分野では, 有機材料以外の材料へのニーズが高 い。例えば PBW においても $\mathrm{Si}$ など半導体材料の微細加工 例(4)が報告されているものの, 機械的・化学的に優れ, 微細 構造がそのまま利用可能なガラス, セラミックス, 半導体, 金属材料等の微細加工には, レジストに比べて高いイオン 照射量を要するなどの課題があると考えられる。本研究グ ループでも有機・無機シロキサンによる $\mathrm{SiO}_{2}$ のパターニン グ形成が可能であることを確認している(20)。

例えば，Fig.8 に示すインプリント用の型加工のための微 細加工上の課題は，電鋳適応性を考慮したレジスト選択で ある。レジスト選択に当たっては, 現状で $\mathrm{PBW}$ への適用上 実績のあるポジ型の PMMA およびネガ型の SU-8 を用いて いるが，高アスペクト比を有する電鋳プロセスに最適とは

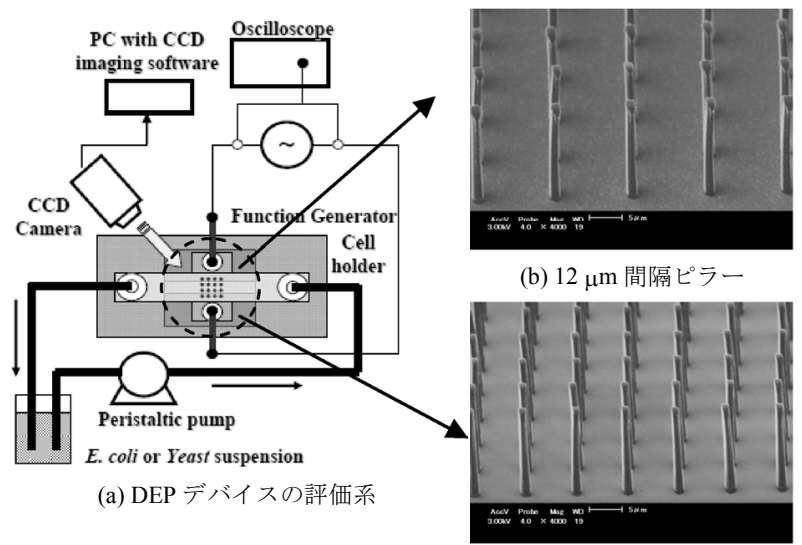

(c) $8 \mu \mathrm{m}$ 間隔ピラー

Fig. 10. (a) Schematic illustration of the DEP device comprising high-aspect pillar arrays with a pitch of (b) $12 \mu \mathrm{m}$ and (c) $8 \mu \mathrm{m}$ in between the gap of the electrode.

いえない。例えば，PMMA は厚膜の形成が難しく 1 回のス ピンコートによる膜厚は数 $\mu \mathrm{m}$ 程度にとどまる。また厚膜が 形成可能な SU-8 は強度も高く MEMS 用の永久膜としては 有利だが, 電鋳後の剥離が困難である。現在, 主要なレジ ストメーカの協力を得て, 電鋳用の母型作製に適した PBW 用レジストを既存の EB 用レジス卜群の中から探索してい る。

また, 今後 $\mathrm{EB}$ 描画などの先行技術と差別化を図り, PBW を産業界に広く普及させてゆくためには，高エネルギーイ オンの高い LET を活用した放射線化学反応を活かし, ユニ ークな微細加工技術を見出してゆくことが必要である。

\section{4. まとめ}

本稿においては，PBW 技術の概要と筆者らの取り組みに ついて紹介した。現在, 急速に開発が進むナノインプリン ト用金型やバイオ用微小流体デバイス, MEMS など微細加 工への多様な二ーズの要求に対応するべく, 未探索の材料 における照射効果を調査する必要がある。また, 今後の普 及に向けて, 小型の PBW 装置の開発が推進されることで, PBW は研究室での学術的研究対象から, 今後は EB 露光と 同様に一般加工技術としての展開が期待される。高アスペ クト比構造など加工形状の特徵に加え, 高エネルギーイオ ンビームによる加工速度の改善が, 微細加工の利用促進に 寄与することも期待される。加工技術としての完成度はま だまだであるが潜在的加工性能は高く, 今後, 本手法が適 用な材料の多様化を図る必要がある。また, 高エネルギー イオンビーム特有の表面の改質効果により, 材料の微細領 域での高機能化のための研究への取り組みも期待される。

\section{謝 辞}

本研究は, 一部, 文部科学省私立大学学術研究高度化事 業 (学術フロンティア), 日本学術振興会科学研究費基盤研 究(B)(No.17310085) の支援を受けて行われた。集束プロト ンビーム描画実験は, 日本原子力研究開発機構 (JAEA) 高 崎量子応用研究所との共同研究により行われた。日頃, ご 
議論，ご指導賜っている JAEA および芝浦工大 CFM の共同 研究者の皆様, 大阪府立大学平井義彦先生, 首都大学東京 内田諭先生に深く感謝致します。

(平成 20 年 4 月 28 日受付)

\section{文献}

(1) International Technology Roadmap for Semiconductors (ITRS) 2005 edition, http://www.itrs.net/

和訳は（社）電子情報技術産業協会（JEITA）の半導体技術ロードマ ップ専門委員会, http://strj-jeita.elisasp.net/strj/

（2）江刺正喜：「シリコン MEMS の新潮流」，応用物理, Vol.73, No.9, pp.1158-1165 (2004)

(3) 北森武彦・田中有希:「マイクロ化学バイオチップ入門」, 応用物理, Vol.74, No.5, pp.623-627 (2005)

(4) F. Watt, M. B. H. Breese, A. A. Bettiol, and J. A. van Kan : "Proton beam writing”, Materials Today, Vol.10, No.6, pp.20-29 (2007)

（5）野末 寬・遠藤章宏・樋口 朗・笠原春生・島津信夫：「次世代電子 線露光装置の開発」, 応用物理, Vol.71, No.4, pp.421-424 (2002)

(6) 岡崎信次 : 「リソグラフィー技術の将来展望」, 応用物理, Vol.75, No.11, p.1328-1334 (2006)

( 7 ) J. A. van Kan, A. A. Bettiol, and F. Watt : "Proton Beam Writing of Three-Dimensional Nanostructures in Hydrogen Silsesquioxane", Nano Lett.,Vol.6, No.3, pp.579-582 (2006)

(8) J. F. Ziegler : The Stopping and Range of Ions in Matter, Vol.2-6, Pergamon Press (1977-1985); 関連ウェブサイト http://www.srim.org.

(9) P. Hovington, D. Drouin, and R. Gauvin : "Casino: A New Era of Monte Carlo Code in $\mathrm{C}$ Language for Electron Beam Interaction, Part I: Description of the Program", Scanning, Vol.19, pp.1-14 (2007); 関連ウェ ブサイト http://www.gel.usherbrooke.ca/casino/

(10) 西川宏之 - 打矢直之 - 古田祐介 - 吉田栄治 - 芳賀潤二 - 及川将一 佐藤隆博・石井保行・神谷富裕：「集束プロトンビーム描画による微 細加工と型加工への応用」, 成形加工, Vol.19, No.5, pp.276-281 (2007)

(11) N. Uchiya, T. Harada, M. Murai, H. Nishikawa, J. Haga, T. Sato, Y. Ishii, and T. Kamiya : "Micro-machining of resists on silicon by proton beam writing”, Nucl. Instr. Meth. Phys. Res. B, Vol.260, No.1, pp.405-408 (2007)

(12) 芝浦工業大学 先端工学研究機構フレキシブル微細加工研究センタ 一 : http://www.cfm.ae.shibaura-it.ac.jp

(13) Y. Furuta, N. Uchiya, H. Nishikawa, J. Haga, T. Sato, M. Oikawa, Y. Ishii, and T. Kamiya : "Fabrication of three-dimensional structures of resist by proton beam writing”, J. Vac. Sci. Tech. B, Vol.25, Issue 6, pp.2171-2174 (2007)
(14) N. Uchiya, Y. Furuta, H. Nishikawa, T. Watanabe, J. Haga, T. Satoh, M. Oikawa, Y. Ishii, and T. Kamiya : "Ni electroplating on a resist micro-machined by proton beam writing", Microsystem Technologies (2008) (Published online 29 Jan.2008)

(15) 関 佳裕 - 西川宏之 - 打矢直之 - 古田祐介 - 芳賀潤二 - 及川将一 佐藤隆博・石井保行・神谷富裕:「集束陽子線による微細構造の PDMS による転写」, 応用物理学関係連合講演会, No.2, 29a-ZL-19, p.732 (2008)

(16) Y. Furuta, N. Uchiya, H. Nishikawa, J. Haga, M. Oikawa, T. Satoh, Y. Ishii, T. Kamiya, R. Nakao, and S. Uchida : "Fabrication of High-Aspect-Ratio Pillars by Proton Beam Writing and Application to DEP-Devices", 20th Microprocesses and Nanotechnology Conference, pp.340-341, Paper No.6A-4-139 (2007)

(17) 円城寺隆治・尼子恵里・内田 諭・枋久保文嘉 :「インピーダンス計 測法による損傷大腸菌の誘電泳動特性解析」, 静電気学誌, Vol.31, No.1, pp.8-13 (2007)

(18) 中尾亮太 - 内田 諭・古田祐介・西川宏之：「三次元構造誘電泳動デ バイスにおける微生物の捕集特性」, 第 55 回応用物理学関係連合講 演会, 29p-R-9, p.1371 (2008)

(19) 古田祐介 - 打矢直之 - 西川宏之 - 芳賀潤二 - 及川将一 - 佐藤隆博 石井保行・神谷富裕・中尾亮太・内田 諭：「集束プロトンビーム微 細加工を応用した微生物濃縮セルの作製と評価」, 第 55 回応用物理 学関係連合講演会, No.3, 29p-R-9, p.1371 (2008)

(20) 土屋龍太郎・古田祐介・打矢直之・西川宏之・芳賀潤二 - 及川将一 佐藤隆博・石井保行・神谷富裕：「シロキサン系薄膜の集束イオンビ 一ム描画による微細加工」, 第 55 回応用物理学関係連合講演会, No.2, 30p-ZL-2, p.750 (2008)

西川宏之 (正員) 1964 年 4 月 5 日生。1993 年 3 月早稲

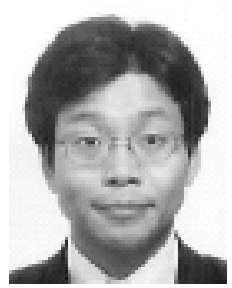
田大学大学院理工学研究科博士後期課程修了。 同年 4 月東京都立大学工学部助手, 2000 年 4 月芝浦工業大学工学部電気工学科講師, 2003 年 4 月助教授を経て, 2006 年 4 月准教授, 先端 工学研究機構フレキシブル微細加工研究セン ター長。現在に至る。誘電体の電気電子・光物 性, 光・イオン等の量子ビームを利用した微細 加工・改質とその応用に関する研究に従事。 